\title{
Land management impacts on European butterflies of conservation concern: a review
}

\author{
Terezie Bubová $^{1} \cdot$ Vladimír Vrabec $^{1} \cdot$ Martin Kulma $^{1} \cdot$ Piotr Nowicki $^{2}$
}

Received: 22 July 2015/ Accepted: 22 October 2015/Published online: 28 October 2015

(C) The Author(s) 2015. This article is published with open access at Springerlink.com

\begin{abstract}
Recent land use changes, namely the intensification of agriculture and forestry as well as the abandonment of traditional grassland management methods, have resulted in the decline of butterfly diversity in Europe. Appropriate management of butterfly habitats is thus required in order to reverse this negative trend. The aim of our study was to review the available literary information concerning the effects of various types of management on European butterflies of conservation concern, and to provide practical recommendations for the management of butterfly habitats. Since vegetation succession is a major threat to butterfly populations, there is a need for activities to suppress this process. Extensive grazing and rotational mowing, which imitate the traditional way of meadow use, appear to be the most suitable management in this respect. Both grazing and mowing should optimally be of low intensity and follow a mosaic design, with different land fragments being successively used at different times. Habitat disturbance through trampling, either associated with grazing or various sporting activities (hiking, biking, horse riding), or through occasional small-area burning, also prove to be beneficial for many butterflies. In the case of woodland species, maintaining open habitats within forests (glades, clearings, wide road verges) and thinning forest stands is recommended. Among the unfavourable management activities identified, the most harmful are
\end{abstract}

Piotr Nowicki

piotr.nowicki@uj.edu.pl

1 Department of Zoology and Fisheries, Czech University of Life Sciences, Kamýcká 129, Suchdol, 16521 Prague 6, Czech Republic

2 Institute of Environmental Sciences, Jagiellonian University, Gronostajowa 7, 30-387 Kraków, Poland afforestation of open lands and drainage works. Therefore, such activities must be stopped at butterfly sites in order to ensure the effective conservation of species of conservation concern.

Keywords Agriculture $\cdot$ Biodiversity $\cdot$ Forestry $\cdot$ Habitat management $\cdot$ Land use $\cdot$ Species conservation

\section{Introduction}

European landscapes and their use by agriculture and forestry have been undergoing considerable changes in recent decades (Reidsma et al. 2006). These changes have typically led to the cessation of the traditional use of seminatural habitats, causing either the complete abandonment of land or the introduction of intensive agriculture and forestry (Balmer and Erhardt 2000; Young et al. 2005). Both processes are considered prominent threats to biodiversity in Europe (Morris 2000; Benton et al. 2003; Saarinen and Jantunen 2005; Young et al. 2005). They have led to the destruction of many habitats as well as to the deterioration of the quality of the remaining habitat fragments (Begon et al. 2006). They have also affected the spatial structure of habitats, usually increasing their fragmentation, which threatens the survival of numerous species (Krauss et al. 2005; Pöyry 2007). One of the main groups of organisms negatively affected by these processes are butterflies (Öckinger and Smith 2006; Wenzel et al. 2006; Körösi et al. 2012).

On the other hand, through proper conservation-oriented land management we are able to enhance the chances of butterfly survival even in severely altered and fragmented landscapes. Management activities may improve the quality of habitat patches of individual species (Kruess and 
Tscharntke 2002; Sawchik et al. 2003; Wenzel et al. 2006). This is particularly true for many endangered butterflies, which have suffered from long-term land abandonment leading to meadow succession and subsequent penetration by shrubs and trees (Morris 2000; Hula et al. 2004; Pöyry et al. 2006).

However, high quality habitat patches do not always foster species occurrence. Even if a patch fulfils all of the species requirements, individuals will not occur there as long as the patch is too isolated and far beyond their ability to disperse (Schtickzelle et al. 2006). Therefore, it is important to maintain well-connected networks of habitat patches (Hanski et al. 1994, 1995; Thomas et al. 2001; Schtickzelle and Baguette 2003; Öckinger and Smith 2007). Again, proper land management may help in this respect by facilitating butterfly dispersal and thus reducing the impact of fragmentation of their habitat patches. This can be achieved either directly through creating corridors and stepping stone habitats (Haddad 1999; Skórka et al. 2013) or indirectly through promoting dispersal behaviour in butterflies (Begon et al. 2006). Dispersal distance and individual willingness to emigrate are key traits for the persistence of populations in fragmented landscapes (Schtickzelle et al. 2005; Fric et al. 2010; Hambäck et al. 2010; Zimmermann et al. 2011).

In our paper we have compiled and reviewed available information regarding the effects of different small-scale land management practices on endangered European butterfly species. By doing so, we aim to drawing general conclusions about their relative role, either positive or negative, in shaping butterfly communities. We also attempt to provide conservation recommendations based on the outcome of our review.

We focused on management activities applicable at the small-scale of nature reserves or Natura 2000 sites, because we believe that such a scale is the most relevant for successful butterfly conservation. First of all, populations of most European butterflies typically exist in relatively small local populations expanding over a few to few tens of hectares (Warren 1992). Apart from this, small-scale conservation actions, following the principle of "think globally, act locally", proved to be more effective for butterflies (cf. Thomas et al. 2011), although obviously their applicability (or preventing in the case of unfavourable management) is affected by large-scale environmental policies.

\section{Review approach}

We conducted a comprehensive search for research papers dealing with the effects of various types of land management on butterflies in Europe, using the Web-of-Knowledge (http://apps.webofknowledge.com/) and Scopus (http:// www.scopus.com/) databases. Wherever possible, we additionally supplemented the information gathered in this way with the material from relevant 'grey literature' known to us.

We focused our review primarily on species of conservation concern that are listed in the European Red List of Butterflies, including those classified as Near Threatened (van Swaay et al. 2010). There is a clear discrepancy in the scientific literature dealing with the conservation of European butterflies, with many papers from Northern and Western Europe, and much lower numbers of those from other parts of the continent. We partly mitigated this problem by including a large bulk of local literature or even unpublished reports, mostly from Central and Eastern Europe. Nevertheless, as many local publications are not easily accessible and/or published in national languages unknown to us, some biases in geographical coverage of our review still remain. In particular, the amount of information we have managed to collect for butterflies with distribution ranges restricted to the Alpine and Mediterranean regions is not as large as that available for species from other regions. However, we strongly believe that the material we have gathered is extensive and comprehensive enough ( $>100$ papers representing almost all European countries) to allow drawing general conclusions about the impacts of various types of habitat management.

We classified the management types into two categories: favourable or unfavourable for butterflies. Their impacts on butterflies of conservation concern have been summarised in Tables 1 and 2. In turn, Fig. 1 presents the relative importance of different management types for butterflies. Below, we discuss their effects in a systematic way.

\section{Favourable management}

\section{Rotational mowing}

One of the most effective ways for the conservation for endangered butterflies through meadow management is rotational mosaic mowing, usually complemented by extensive grazing as described below (Saarinen and Jantunen 2005; Farruggia et al. 2012). Rotational mosaic mowing implies successive mowing of different meadow fragments (Morris and Rispin 1987; Saarinen and Jantunen 2005; Novák et al. 2007; Gaisler et al. 2011). This mowing method resembles traditional meadow management (Pöyry 2007), the abandonment of which has led to the decline of numerous meadow specialists, including the endangered Colias myrmidone (Esper, 1781) (Konvička et al. 2008a) or charismatic large blue butterflies of the genus Maculinea (=Phengaris), which are flagships of grassland conservation in Europe (Thomas et al. 2009). The future survival of the aforementioned species is dependent on the application 
Table 1 Positive effects of habitat management on European butterflies of conservation concern documented in the literature

\begin{tabular}{|c|c|c|c|c|c|c|c|}
\hline \multirow[t]{2}{*}{ Species } & \multirow[t]{2}{*}{ Status } & \multicolumn{6}{|c|}{ Favourable management type } \\
\hline & & $\begin{array}{l}\text { Rotational } \\
\text { mowing }\end{array}$ & $\begin{array}{l}\text { Extensive } \\
\text { grazing }\end{array}$ & Trampling & $\begin{array}{l}\text { Occasional } \\
\text { burning }\end{array}$ & Fallowing & $\begin{array}{l}\text { Maintenance of sparse forest } \\
\text { stands }\end{array}$ \\
\hline Archon apollinus & NT & & 80 & & & & \\
\hline Aricia anteros & NT & & & & & 72 & \\
\hline Boloria chariclea & NT & 9 & & & & & \\
\hline Boloria titania & NT & 13,73 & 13 & & & & \\
\hline Carcharodus flocciferus & NT & 24,4 & 24 & & & & \\
\hline Carcharodus lavatherae & NT & 86,4 & 14,86 & & & & \\
\hline Chazara briseis & NT & & $35,38,39$ & 26,35 & & & \\
\hline Coenonympha hero & VU & 11 & & 10 & & & \\
\hline Coenonympha oedippus & EN & 62,69 & 17 & & & & \\
\hline Coenonympha orientalis & VU & & & & & & 50 \\
\hline Coenonympha phryne & $\mathrm{CR}$ & 85 & 86 & & & & \\
\hline Coenonympha tullia & VU & 94 & 85,94 & & 20 & 94 & \\
\hline Colias chrysotheme & VU & & 48 & 85,4 & & & \\
\hline Colias hecla & NT & 85 & 85 & & & & \\
\hline Colias myrmidone & EN & 45 & $45,78,90$ & & & & \\
\hline Cupido decoloratus & NT & & & 4,5 & & & \\
\hline Erebia christi & VU & & 52 & & & & \\
\hline Erebia claudina & NT & & 85 & & & & 85 \\
\hline Erebia epistygne & NT & & 87 & & & & 87 \\
\hline Erebia flavofasciata & NT & & 15 & & & & 50 \\
\hline Erebia sudetica & VU & & & & & & $4,47,51$ \\
\hline Euphydryas desfontainii & NT & & 63,63 & 64 & & & \\
\hline Euphydryas iduna & NT & & & & & & 49 \\
\hline Euphydryas maturna & VU & & & & & & $1,19,29,93$ \\
\hline Gonepteryx cleobule & VU & & & & & & 50 \\
\hline Gonepteryx maderensis & EN & & & & & & 85 \\
\hline Hipparchia bacchus & VU & & & & & 50 & \\
\hline Hipparchia fagi & NT & & 66 & 4 & 57 & & \\
\hline Hipparchia hermione & NT & & 4 & & 4 & & 4,66 \\
\hline Hipparchia statilinus & NT & & 4 & 65 & 4 & & \\
\hline Hipparchia tilosi & VU & & & & & & 50 \\
\hline Iolana iolas & NT & & 58 & 68 & 58 & & \\
\hline Leptidea morsei & NT & & & & & & $4,18,34$ \\
\hline Lopinga achine & VU & & 4 & & & & $6,7,46,77$ \\
\hline Lycaena helle & EN & $4,28,30$ & $3,30,31$ & 75 & & & \\
\hline Maniola halicarnassus & NT & 50 & & & & & \\
\hline Melitaea aurelia & NT & 4 & 4,27 & 27,40 & & & \\
\hline Melitaea britomartis & NT & & 4,12 & & & & \\
\hline Muschampia cribrellum & NT & 41 & 22 & & & & \\
\hline Pararge xiphia & EN & & 71 & & & & 37 \\
\hline Parnassius apollo & NT & & 8,70 & 70 & & & \\
\hline Parnassius mnemosyne & NT & & & & & & $43,55,84$ \\
\hline Parnassius phoebus & NT & 85 & & & & & \\
\hline Phengaris arion & EN & 74,76 & 76,82 & 82 & & & \\
\hline Phengaris nausithous & NT & $32,36,59$ & 59 & 44 & 60 & & \\
\hline Phengaris teleius & VU & 36,83 & $32,59,96,97$ & 44 & 60 & & \\
\hline
\end{tabular}


Table 1 continued

\begin{tabular}{|c|c|c|c|c|c|c|c|}
\hline \multirow[t]{2}{*}{ Species } & \multirow[t]{2}{*}{ Status } & \multicolumn{6}{|c|}{ Favourable management type } \\
\hline & & $\begin{array}{l}\text { Rotational } \\
\text { mowing }\end{array}$ & $\begin{array}{l}\text { Extensive } \\
\text { grazing }\end{array}$ & Trampling & $\begin{array}{l}\text { Occasional } \\
\text { burning }\end{array}$ & Fallowing & $\begin{array}{l}\text { Maintenance of sparse forest } \\
\text { stands }\end{array}$ \\
\hline Plebejus dardanus & NT & & & 50 & & & \\
\hline Plebejus pylaon & NT & 58 & 4,58 & & 58 & & \\
\hline Plebejus trappi & NT & & 85 & & & & \\
\hline Plebejus zullichi & EN & & & & & 2 & \\
\hline Polyommatus eros & NT & & 95 & & & & \\
\hline Polyommatus galloi & VU & & 23 & & & & \\
\hline Polyommatus humedasae & EN & & & 87,89 & 87 & & \\
\hline $\begin{array}{l}\text { Polyommatus } \\
\text { nephohiptamenos }\end{array}$ & NT & 85 & & & & & 85 \\
\hline Polyommatus damon & NT & 4 & 25 & 79 & & & \\
\hline Polyommatus dorylas & NT & & 86 & & & & \\
\hline Polyommatus nivescens & NT & 89 & & & & & \\
\hline Polyommatus orphicus & VU & & & & 42 & & \\
\hline Pseudochazara amymone & VU & 16 & 16 & & & & 92 \\
\hline $\begin{array}{l}\text { Pseudochazara } \\
\text { cingovskii }\end{array}$ & $\mathrm{CR}$ & & & 92 & & & \\
\hline Pseudochazara euxina & EN & & 50 & & & & \\
\hline Pseudochazara orestes & VU & & & & & & 85 \\
\hline Pseudophilotes panoptes & NT & & 61,68 & 61 & & & \\
\hline Pseudophilotes vicrama & NT & & $4,31,86$ & 4 & & & \\
\hline Pyrgus cirsii & VU & 33 & 85 & & & & \\
\hline Thymelicus acteon & NT & 4,81 & & & & 56 & \\
\hline Tomares nogelii & VU & 21 & & & & & 85 \\
\hline Turanana taygetica & EN & & & 89 & & 89 & \\
\hline Zerynthia cerisy & NT & 53,54 & & & & & \\
\hline
\end{tabular}

The species conservation status follows the European Red List of Butterflies (van Swaay et al. 2010): $C R$ critically endangered, $E N$ endangered, $V U$ vulnerable, $N T$ near threatened. Numbers in the table refer to the papers reporting the effects: (1) AOPK (2011); (2) Barea-Azcón et al. (2014); (3) Bauerfeind et al. (2009); (4) Beneš et al. (2002); (5) Beneš et al. (2003); (6) Bergman (1999); (7) Bergman (2001); (8) Bohlin et al. (2008); (9) Britten and Brussard (1992); (10) Cassel et al. (2001); (11) Cassel et al. (2008); (12) Cerrato et al. (2014); (13) Cozzi et al. (2008); (14) Coutsis and Ghavalás (2001); (15) Cupedo (2000); (16) Cuvelier and Mølgaard (2015); (17) Čelik et al. (2009); (18) Čelik (2013); (19) Čizek and Konvička (2005); (20) Dennis and Eales (1997); (21) Dincă et al. (2009); (22) Dincă et al. (2010); (23) Dinca et al. (2013); (24) Dolek and Geyer (1997); (25) Dolek and Geyer (2002); (26) Dover and Settele (2009); (27) Eichel and Fartmann (2008); (28) Fischer et al. (1999); (29) Freese et al. (2006); (30) Goffart et al. (2010); (31) Grill and Cleary (2003); (32) Grill et al. (2008); (33) Guillaumin (1972); (34) Höttinger (2004); (35) Johannesen et al. (1997); (36) Johst et al. (2006); (37) Jones and Lace (1992); (38) Kadlec et al. (2009); (39) Kadlec et al. (2010); (40) Kleyer et al. (2007); (41) Kolev (2003); (42) Kolev (2005); (43) Konvička and Kuras (1999); (44) Konvička et al. (2005); (45) Konvička et al. (2008a); (46) Konvička et al. (2008b); (47) Konvička et al. (2014); (48) Korb (1994); (49) Kozlov and Kullberg (2008); (50) Kudrna et al. (2015); (51) Kuras et al. (2003); (52) Leigheb et al. (1998); (53) Lelo and Spasojević (2012); (54) Lelo (2000); (55) Luoto et al. (2001); (56) Louy et al. (2007); (57) Möllenbeck et al. (2009); (58) Munguira and Martín (1993); (59) Novák et al. (2007); (60) Nowicki et al. (2015); (61) Obregón et al. (2014); (62) Örvössy et al. (2013); (63) Pennekamp et al. (2013); (64) Pennekamp et al. (2014); (65) Pinzari (2009); (66) Pinzari and Sbordoni (2013); (67) Rabasa et al. (2007); (68) Settele et al. (2008);(69) Settele (2010); (70) Schmeller et al. (2011); (71) Shreeve and Smith (1992); (72) Schurian (1995); (73) Schweiger et al. (2008); (74) Sielezniew and Rutkowski (2012); (75) Skórka et al. (2007); (76) Spitzer et al. (2009); (77) Streitberger et al. (2012); (78) Szentirmai et al. (2014); (79) Šlancarová et al. (2012); (80) Šlancarová et al. (2015); (81) Thomas et al. (1992); (82) Thomas (1995); (83) Thomas et al. (2009); (84) Välimäki and Itämies (2003); (85) van Swaay and Warren (1999); (86) van Swaay (2002); (87) van Swaay et al. (2010); (88) van Swaay et al. (2012); (89) van Swaay et al. (2011); (90) Verovnik et al. (2011); (91) Verovnik et al. (2013); (92) Verovnik et al. (2014); (93) Vrabec (2001); (94) Weking et al. (2013); (95) Wiemers et al. (2010); (96) Witek et al. (2010); (97) Witek et al. (2011)

of meadow management, which should follow the principles of rotational mosaic mowing. These principles involve (i) relatively low mowing intensity, with a single fragment being mown no more than once per year, and (ii) mowing different fragments at different times in order to ensure heterogeneous turf height within meadows (Morris 2000). A higher mowing frequency may be beneficial for xerophilous species, which prefer short vegetation, e.g., 
Table 2 Negative effects of habitat management on European butterflies of conservation concern documented in the literature

\begin{tabular}{|c|c|c|c|c|c|}
\hline \multirow[t]{2}{*}{ Species } & \multirow[t]{2}{*}{ Status } & \multicolumn{4}{|c|}{ Unfavourable management type } \\
\hline & & Afforestation & Drainage & Intensive agriculture & Intensive forestry \\
\hline Aricia anteros & NT & & & 30,70 & \\
\hline Boloria chariclea & NT & & & 71 & \\
\hline Boloria improba & EN & & & 80 & \\
\hline Boloria polaris & VU & & & 47 & \\
\hline Boloria titania & NT & & 12 & & \\
\hline Carcharodus flocciferus & NT & & & $4,20,45$ & \\
\hline Carcharodus lavatherae & NT & 4,81 & & 81 & \\
\hline Chazara briseis & NT & 31 & & 34,66 & \\
\hline Coenonympha hero & VU & 10 & & 9 & \\
\hline Coenonympha oedippus & EN & 65,79 & $56,65,79$ & 13,56 & \\
\hline Coenonympha phryne & $\mathrm{CR}$ & 80 & & 80,85 & \\
\hline Coenonympha tullia & VU & $16,61,90$ & $16,32,33$ & & \\
\hline Colias chrysotheme & VU & 4,80 & & 80 & \\
\hline Colias myrmidone & EN & 41,74 & & 23,41 & \\
\hline Cupido decoloratus & NT & 4 & & & \\
\hline Erebia christi & VU & & & & 84 \\
\hline Erebia claudina & NT & & & 80 & \\
\hline Erebia epistygne & NT & & & 15 & \\
\hline Erebia sudetica & VU & 43,48 & & 43 & \\
\hline Euchloe bazae & VU & & & 80 & \\
\hline Euphydryas desfontainii & NT & & 57,58 & 58 & \\
\hline Euphydryas iduna & NT & 46 & 46 & & \\
\hline Euphydryas maturna & VU & $24,40,88$ & & $1,80,88$ & \\
\hline Gonepteryx cleobule & VU & & & 47 & \\
\hline Gonepteryx maderensis & EN & & 80 & & 80 \\
\hline Hipparchia bacchus & VU & & & 47 & \\
\hline Hipparchia fagi & NT & $53,60,68$ & & 53 & \\
\hline Hipparchia hermione & NT & 4,60 & & & \\
\hline Hipparchia leighebi & NT & & & 47,82 & \\
\hline Hipparchia sbordonii & NT & & & 82 & \\
\hline Hipparchia statilinus & NT & 59 & & 4,59 & \\
\hline Iolana iolas & NT & 62 & & 62,63 & \\
\hline Leptidea morsei & NT & 14,29 & & 14,80 & \\
\hline Lopinga achine & VU & 5,42 & & 36,73 & \\
\hline Lycaena helle & EN & 3,27 & 28 & $3,25,27$ & \\
\hline Melitaea aurelia & NT & 21,64 & & 45 & \\
\hline Melitaea britomartis & NT & $11,44,45$ & 11 & 4 & \\
\hline Muschampia cribrellum & NT & & & 18,37 & \\
\hline Oeneis norna & NT & & 6 & & \\
\hline Pararge xiphia & EN & 69 & & 69 & \\
\hline Parnassius apollo & NT & $17,50,55$ & & & 50 \\
\hline Parnassius mnemosyne & NT & 39,78 & & & $39,51,52$ \\
\hline Parnassius phoebus & NT & 80 & & 80 & \\
\hline Phengaris arion & EN & & 8 & 72 & \\
\hline Phengaris nausithous & NT & & 22,35 & 91 & \\
\hline Phengaris teleius & VU & & 22,35 & 91 & \\
\hline Pieris cheiranthi & EN & & 80 & & \\
\hline
\end{tabular}


Table 2 continued

\begin{tabular}{|c|c|c|c|c|c|}
\hline \multirow[t]{2}{*}{ Species } & \multirow[t]{2}{*}{ Status } & \multicolumn{4}{|c|}{ Unfavourable management type } \\
\hline & & Afforestation & Drainage & Intensive agriculture & Intensive forestry \\
\hline Pieris wollastoni & $\mathrm{CR}$ & & & 82 & \\
\hline Plebejus dardanus & NT & & & 47 & \\
\hline Plebejus pylaon & NT & & & 53 & \\
\hline Plebejus trappi & NT & & 80 & 80 & \\
\hline Plebejus zullichi & EN & & & 53 & \\
\hline Polyommatus eros & NT & 89 & & 89 & \\
\hline Polyommatus galloi & VU & & & 19 & \\
\hline Polyommatus golgus & VU & & & 47,89 & \\
\hline Polyommatus humedasae & EN & 80 & & & \\
\hline Polyommatus nephohiptamenos & NT & & 80 & 80 & \\
\hline Polyommatus damon & NT & 4,75 & 4 & 75 & \\
\hline Polyommatus dorylas & NT & 80 & & & \\
\hline Polyommatus nivescens & NT & 82 & & & \\
\hline Polyommatus orphicus & VU & 38 & & 38 & \\
\hline Polyommatus violetae & VU & 47 & & 47 & \\
\hline Pseudochazara amymone & VU & & & 87 & \\
\hline Pseudochazara cingovskii & $\mathrm{CR}$ & & & 87 & \\
\hline Pseudochazara euxina & EN & & & 47 & \\
\hline Pseudophilotes panoptes & NT & 55 & & 55,82 & \\
\hline Pseudophilotes vicrama & NT & 4,26 & & & \\
\hline Pyrgus cirsii & VU & 80 & & 80 & \\
\hline Thymelicus acteon & NT & & & $49,77,76$ & 4 \\
\hline Tomares nogelii & VU & 17,80 & & 17 & 80 \\
\hline Turanana taygetica & EN & & & 82 & \\
\hline Zegris eupheme & NT & & & 47 & \\
\hline Zerynthia cerisy & NT & & 2 & & \\
\hline
\end{tabular}

The species conservation status follows the European Red List of Butterflies (van Swaay et al. 2010): $C R$ critically endangered, $E N$ endangered, $V U$ vulnerable, $N T$ near threatened. Numbers in the table refer to the papers reporting the effects: (1) AOPK (2011); (2) Atay (2012); (3) Bauerfeind et al. (2009); (4) Beneš et al. (2002); (5) Bergman (1999); (6) Bolotov (2011); (7) Brommer and Fred (1999); (8) Casacci et al. (2011); (9) Cassel and Tammaru (2003); (10) Cassel et al. (2008); (11) Cerrato et al. (2014); (12) Cozzi et al. (2008); (13) Čelik et al. (2009); (14) Čelik (2013); (15) de Arce-Crespo et al. (2009); (16) Dennis and Eales (1997); (17) Dincă et al. (2009); (18) Dincă et al. (2010); (19) Dinca et al. (2013); (20) Dolek and Geyer (1997); (21) Eichel and Fartmann (2008); (22) Elmes et al. (1998); (23) Freese et al. (2005); (24) Freese et al. (2006); (25) Goffart et al. (2010); (26) Grill and Cleary (2003); (27) Habel et al. (2011a); (28) Habel et al. (2011b); (29) Höttinger (2004); (30) Hüseyinoğlu (2013); (31) Johannesen et al. (1997); (32) Joy and Pullin (1997); (33) Joy and Pullin (1999); (34) Kadlec et al. (2009); (35) KajzerBonk et al. (2013); (36) Kodandaramaiah et al. (2012); (37) Kolev (2003); (38) Kolev (2005); (39) Konvička and Kuras (1999); (40) Konvička et al. (2005); (41) Konvička et al. (2008a); (42) Konvička et al. (2008b); (43) Konvička et al. (2014); (44) Koren et al. (2011); (45) Koren and Jugovic (2012); (46) Kozlov and Kullberg (2008); (47) Kudrna et al. (2015); (48) Kuras et al. (2003); (49); Louy et al. (2007); (50) Łozowski et al. (2014); (51) Luoto et al. (2001); (52) Meier et al. (2005); (53) Möllenbeck et al. (2009); (54) Munguira and Martín (1993); (55) Obregón et al. (2014); (56) Örvössy et al. (2013); (57) Pennekamp et al. (2013); (58) Pennekamp et al. (2014); (59) Pinzari (2009); (60) Pinzari and Sbordoni (2013); (61) Pocewicz et al. (2009); (62) Rabasa et al. (2007); (63) Rabasa et al. (2008); (64) Sang et al. (2010); (65) Settele (2010); (66) Seufert and Grosser (1996); (67) Schmeller et al. (2011); (68) Schmitt and Rákosy (2007); (69) Shreeve and Smith (1992); (70) Schurian (1995); (71) Simonsen (2005); (72) Spitzer et al. (2009); (73) Streitberger et al. (2012); (74) Szentirmai et al. (2014); (75) Ślancarová et al. (2012); (76) Thomas (1995); (77) Thomas et al. (2001); (78) Välimäki and Itämies (2003); (79) van Halder et al. (2008); (80) van Swaay and Warren (1999); (81) van Swaay (2002); (82) van Swaay et al. (2011); (83) van Swaay et al. (2010); (84) van Swaay et al. (2012); (85) Verovnik et al. (2013); (86) Verovnik et al. (2013); (87) Verovnik et al. (2014); (88) Vrabec (2001); (89) Wiemers et al. (2010); (90) Weking et al. (2013); (91) Wynhoff et al. (2011)

Coenonympha phryne (Pallas, 1771) (van Swaay and Warren 1999).

Mowing should optimally take place outside the flight periods of target butterfly species so as to maintain high availability of nectar sources for their imagoes, and a sufficient number of host plants for oviposition (Johst et al. 2006; Mládek et al. 2006; Dover et al. 2010; Wynhoff et al. 2011). This may be a serious limitation if several target 
Fig. 1 Numbers of European butterfly species of conservation concern affected by various types of habitat management. Shades of gray indicate different conservation status according to the European Red List of Butterflies (van Swaay et al. 2010): $N T$ near threatened, $V U$ vulnerable, $E N$ endangered, $C R$ critically endangered

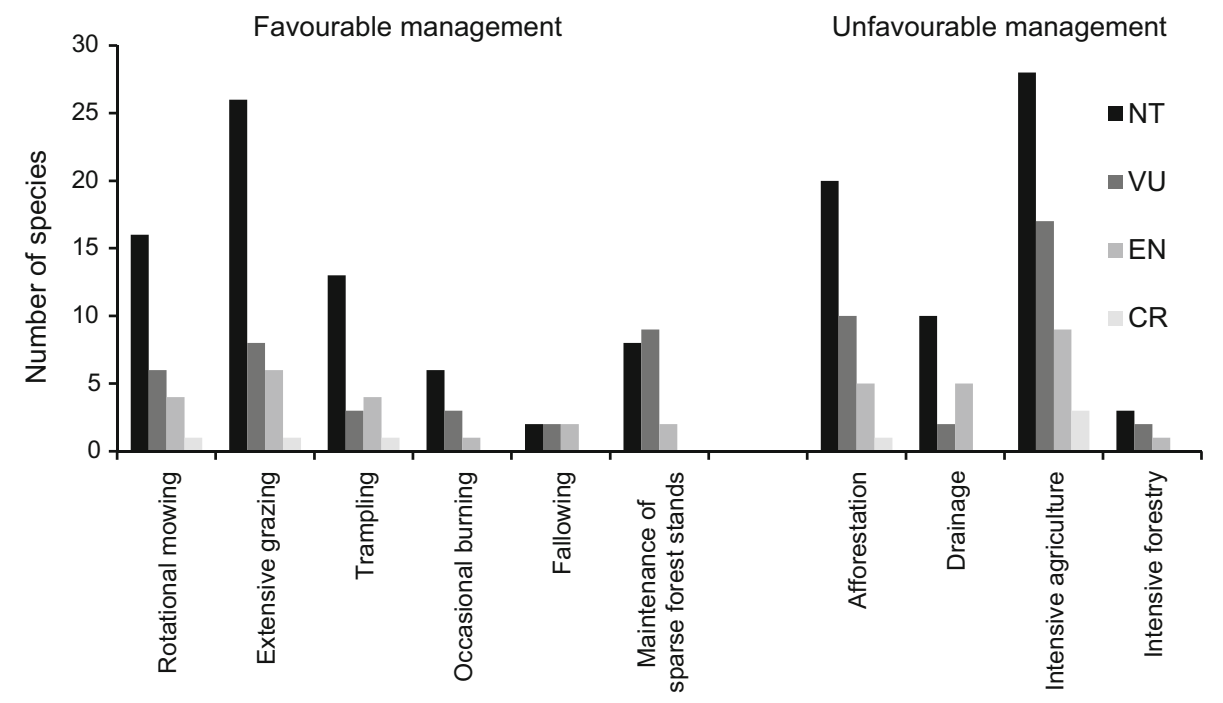

species occur sympatrically at the same site, which is frequently the case with Maculinea butterflies (Sliwinska et al. 2006). In fact, mowing timing must be further restricted in the case of Maculinea butterflies due to their myrmecophilous lifestyle (Thomas 1995; Witek et al. 2011). Since the adoption of larvae by ants is a key process for Maculinea survival (Thomas 1995; Witek et al. 2010; Sielezniew and Rutkowski 2012), mowing should be conducted only after adoption occurs, i.e., in the second half of September at the earliest (Grill et al. 2008); this guideline likely applies for the conservation of other myrmecophilous butterflies. Furthermore, strong association with ants, which depend on microhabitat conditions in the soil (Elmes et al. 1998), precludes the use of mulching mowers for the management of sites inhabited by myrmecophilous species (Marhoul and Turoňová 2007). In general, mulching is the most devastating method of mowing meadows (Humbert et al. 2010), and it should be discouraged. In addition, Humbert et al. (2010), who investigated the effects of different moving techniques on meadows, found that using motor bar mowers is much better than utilizing rotary mowers.

\section{Extensive grazing}

Historically, extensive grazing was applied in grasslands and woodlands together with other types of management. It constituted an effective way of suppressing vegetation succession, thus improving the quality of habitats for numerous butterfly species. In order to benefit butterfly communities, grazing has to be appropriately planned according to its load (i.e., number of livestock units per area unit), types of grazing animals, and grazing period (Morris 2000; Háková et al. 2005; Pöyry et al. 2006). A generally accepted rule is that the optimal sampling intensity should be 0.2 livestock units per hectare, and it should not exceed 0.5 livestock units; this was proved by various studies, such as those on Colias myrmidone (Konvička et al. 2008a) Carcharodus flocciferus (Zeller, 1847) (Dolek and Geyer 1997), Euphydryas desfontainii (Godart, 1819) (Pennekamp et al. 2013), Parnassius apollo (Linneaus, 1758) (Schmeller et al. 2011).

The principle that grazing intensity needs to be limited is well exemplified in the endangered Lycaena helle (Denis \& Schiffermüller, 1775) (Habel et al. 2011b). The species is a typical meadow specialist, inhabiting humid, seminatural meadows, which were historically maintained by grazing and haymaking (Konvička et al. 2005; Bauerfeind et al. 2009). The introduction of intensive grazing or mowing resulted in local extinctions of the species. Conversely, leaving such sites without any management leads to meadow overgrowth and the disappearance of the species habitats in the long term perspective (Hula et al. 2004; Habel et al. 2010). An appropriate method of management for Lycaena helle involves reducing the intensity of grazing and introducing a mosaic mowing, thereby achieving an imitation of traditional farming methods that used to maintain fine-grained mosaic landscapes with different managements (Skórka et al. 2007). This system is also appropriate for other endangered butterflies, such as Melitaea aurelia (Nickerl, 1850) (Kleyer et al. 2007). In contrast, Eichel and Fartmann (2008) argued that intensive grazing can also be beneficial for this species as long as it is done once in a few years and some land fragments are left ungrazed.

The type of farm animals kept is important due to the different ways they graze. Sheep grazing has been shown to have a negative impact on the near threatened species Polyommatus damon (Dolek and Geyer 2002). In turn for Pseudophilotes vicrama (Christoph, 1887) it is optimal to 
extensively graze goats and sheep within large fenced enclosures, and to gradually move them over a wide area (Beneš et al. 2002; Grill and Cleary 2003). A related specis, Polyommatus dorylas (Denis \& Schiffermüller, 1775), requires extensive grazing combined with the active removal of bushes and tree seedlings; in contrast, intensive grazing by sheep threatens the persistence of the species (Beneš et al. 2002; van Swaay 2002). The timing and duration of grazing are also important factors (Morris 2000). At localities with endangered butterfly species present it should not be applied during the late spring to mid-summer period as it reduces the availability of larval foodplants and nectar sources for adults. Conversely, grazing is most appropriate during the autumn (SeptemberNovember) and spring (April) (Konvička et al. 2005).

\section{Trampling}

Regular trampling can locally prevent the establishment of vegetation and thus it can supress succession. Historically, butterfly site trampling was caused by grazing animals (Morris 2000; WallisDeVries and Reemakers 2001; Kruess and Tscharntke 2002). Nowadays, artificial trampling by horseback riding, biking or hiking offers a simple and typically costless alternative, which helps to maintain butterfly habitats in early successional stages (Konvička et al. 2005). One species that apparently benefits from trampling is the near threatened Chazara briseis (Linnaeus, 1758), which inhabits steppe-like grasslands (Johannesen et al. 1997). After the penetration of its sites by sheep ceased, the species suffered a serious decline in the Czech Republic, most likely due to the expansion of shrubs (Kadlec et al. 2009). The trampling of habitat patches, either through grazing or through various adventurous sports, is also necessary for the near threatened species Hipparchia statilinus (Hufnagel, 1766) (Beneš et al. 2002; Pinzari 2009). Contrarily, high intensity trampling can also be detrimental for butterfly populations, as was shown in the case of Erebia sudetica (Staudinger, 1861) (Kuras et al. 2003).

\section{Occasional burning}

Occasional burning may, in some cases, be beneficial for butterfly populations (McIver and Macke 2014). Burning reduces the expansion of shrubs, and it is particularly useful for vast and abandoned areas. As a disturbance event, burning typically exerts long-term positive consequences by suppressing succession, but it has a negative impact on the affected populations in the short term (Wolf 2002). However, Nowicki et al. (2015) found absolutely no short-term negative impacts of large-scale fires on the metapopulations of Maculinea teleius and M. nausithous.
In any case, two basic rules of the thumb should be followed when applying burning as a conservation management tool in order to minimalize possible negative shortterm effects. Firstly, small fragments of land should be left unburnt to serve as refuges from which the neighbouring burnt fragments of land can be recolonized (Konvička et al. 2005; Nowicki et al. 2015). Apart from this, burning should occur in seasons when it is likely to be least harmful, i.e., in winter or early spring. Among other examples, burning in winter months has already been successfully applied for the management of sites occupied by Pseudophilotes vicrama (Moore, 1865), Coenonympha tullia (Müller, 1764), or Hipparchia fagi (Scopoli, 1763) (Dennis and Eales 1997; Marttila et al. 1997; Möllenbeck et al. 2009).

\section{Fallowing}

Although (as discussed previously) succession at grassland habitats usually has a negative effect on butterfly communities, there are cases in which vegetation succession can be considered advantageous in its early stages (Skórka et al. 2007; Schirmel and Fartmann 2014). This is particularly true for a relatively large group of butterflies that benefit from the occurrence of high vegetation or shrubs within their grassland habitats. For example, overgrown localities with high grasses and abundant shrubs are optimal sites for Lycaena helle (Skórka et al. 2007; Habel et al. 2011b), and Carcharodus lavatherae (Esper, 1783) (Coutsis and Ghavalás 2001). Thymelicus acteon (Rottemburg, 1775) is another species that profits from succession in its early stages (Beneš et al. 2002; Louy et al. 2007). In all such cases, fallowing may constitute a viable management option; however, it can be utilized only for a limited time period since the continuation of succession, beyond a certain stage, inevitably results in habitat quality deterioration (Skórka et al. 2007).

\section{Maintenance of sparse forest stands}

A majority of woodland butterflies are, in fact, restricted to open habitats within woodlands, which in recent decades have become rare. The reason for this is the abandonment of traditional methods of forest utilization, such as regular clearcuts, tree stand thinning, and forest grazing. The absence of these activities has led to closing of tree canopies and changes in forest vegetation (Kodandaramaiah et al. 2012). Consequently, a number of woodland butterfly species are now endangered in Europe. One such species is Euphydryas maturna (Linnaeus, 1758), which requires insulated glades, sunny spots with young ash trees, and a high availability of nectar plants for its survival (Vrabec 2001; AOPK 2011). Similarly, vulnerable butterflies such as Lopinga achine (Scopoli, 1763), Leptidea morsei 
(Fenton, 1882), and Parnassius mnemosyne (Linnaeus, 1758) need open and sunny habitats within forests, including sparse stands, clearings or road margins (Konvička and Kuras 1999; Luoto et al. 2001; Välimäki and Itämies 2003; Höttinger 2004; Konvička et al. 2008b; Streitberger et al. 2012). Finally, open habitats are also vital for woodland species with caterpillars using grasses as host plants, for instance Hipparchia hermione (Linnaeus, 1764) (Beneš et al. 2002; Pinzari and Sbordoni 2013) and Erebia sudetica (Staudinger, 1861) (Kuras et al. 2001, 2003).

Prescribed forest management is therefore essential for the conservation of most woodland butterflies. Recommended measures should include opening canopies, supressing the growth of tree seedlings within forest glades, supporting forest grazing and promoting coppice management (Slámová et al. 2013). Optimally, tree density should be low enough to allow open spots, which are spaced at least every 300 meters and interconnected with forest roads and clearings (Marhoul and Turoňová 2007). Coppicing, i.e., forest use focused on the production of relatively small diameter wood, for a range of uses including firewood, together with grazing ensured a diverse mosaic of forest microhabitats and created suitable sites for woodland butterflies in the past (Buček 2010). Since both activities are no longer economically viable, financial incentives may be needed to trigger them. Maintaining a network of forest roads with wide margins and strips of herb-rich grassland at forest edges is also recommended (Marhoul and Turoňová 2007).

\section{Unfavourable management}

\section{Afforestation}

The afforestation of formerly open habitats began at the turn of the 18th and 19th centuries, along with the development of modern forestry (Konvička et al. 2005). Currently, afforestation of grassland habitats poses one of the biggest problems for butterflies in Europe, threatening numerous species of conservation concern (van Swaay and Warren 2006; Cassel et al. 2008; Augenstein et al. 2012; Cerrato et al. 2014). It is thus highly regretful that this process is often supported by land management authorities through financial incentives in the form of afforestation grants (MZE 2001). Apart from the direct loss of grassland habitats (van Swaay and Warren 2006), the negative consequences of afforestation stem from the increased fragmentation of remaining habitat patches. Because grassland butterflies have difficulties dispersing through forested landscapes (Nowicki et al. 2014), the effective isolation of existing populations increases, causing overall declines of metapopulations (van Swaay and Warren 2006; Augenstein et al. 2012). Parnassius apollo (Linnaeus, 1758) and Pseudophilotes vicrama (Moore, 1865) are typical examples of butterfly species that suffer from afforestation (Grill and Cleary 2003; Schmeller et al. 2011).

\section{Drainage}

Deliberate drainage or any other processes that drain soil, such as construction works in the vicinity of wet habitats, is a common problem for endangered butterfly conservation (WallisDeVries and Ens 2010; Kati et al. 2012). Wet meadow specialists, such as Melitaea britomartis (Assmann, 1847) (Cerrato et al. 2014) or Coenonympha tullia, are particularly threatened by drainage because their host plants depend on adequate soil water levels (Dennis and Eales 1997). The same is true for myrmecophilous species such as Maculinea butterflies (Elmes et al. 1998). While drainage in the past was primarily conducted in order to increase the area of arable land, nowadays it is typically imposed as a flood prevention measure, also within protected areas (Mládek et al. 2006). However, there is little justification for such actions, at least from the conservation point of view. A recent study by Kajzer-Bonk et al. (2013) proved that a large-scale flood had absolutely no negative impact on the metapopulations of Maculinea nausithous and M. teleius, which provides a strong argument against 'conservation-oriented' drainage works.

\section{Intensive agriculture}

In many European countries, the current agriculture policy focuses on the intensification of land use and the application of modern agrotechnical methods in order to maximise economic benefits (Mládek et al. 2006; Pöyry 2007). Obviously, any conversion of former grassland habitats to cultivated farmlands will always imply habitat destruction for grassland butterflies (Konvička et al. 2005). Furthermore, the excessive use of insecticides within farmlands has a negative impact on butterfly communities in neighbouring areas (van Swaay and Warren 2006). Nevertheless, even traditional meadow management in the form of mowing and/or grazing may play a negative role if its intensity is too high. Several studies have demonstrated that intensive grazing and mowing lead to a decrease in butterfly species abundance (Balmer and Erhardt 2000; Hula et al. 2004; Saarinen and Jantunen 2005). This negative effect is caused by a significant reduction in the availability of larval host plants. Therefore, meadow specialists with strict trophic requirements, e.g., Maculinea arion (Casacci et al. 2011), M. nausithous, M. teleius (Witek et al. 2010), and Coenonympha hero (Cassel and Tammaru 2003), tend to suffer most. Intensive agriculture 
has a negative effect on other species as well, with $\mathrm{Coe}$ nonympha oedippus (Fabricius, 1787) (Örvössy et al. 2013), Muschampia cribrellum (Eversmann, 1841) (Dincă et al. 2010), and Plebejus pylaon (Fischer, 1832) (Munguira and Martín 1993) serving as examples.

\section{Intensive forestry}

Just as farming intensification decimates the populations of many grassland butterflies, forestry intensification can also bring about negative consequences for their forest dwelling counterparts. Intensive forestry has caused the abandonment of traditional practices, such as forest grazing and coppicing that benefited butterfly communities in the past (Slámová et al. 2013). There are numerous species of conservation concern among butterflies negatively affected by forestry intensification, including Coenonympha tullia, Erebia sudetica, Euphydryas maturna, Hipparchia hermione, Leptidea morsei, Lopinga achine and Parnassius mnemosyne (Dennis and Eales 1997; Luoto et al. 2001; Kodandaramaiah et al. 2012; Streitberger et al. 2012; Čelik 2013; Pinzari and Sbordoni 2013; Konvička et al. 2014). To reverse the current negative trends for all these species, changes in forestry management are highly desirable. Forest management must not be focused exclusively on maximising economic benefits from wood production. Specifically, forest stands should be thinned and occasional sunny enclaves should be created.

\section{Discussion}

Prior to any human land use, grasslands as well as open places within forests, i.e., the habitats preferred by a majority of European butterflies, used to be sustained by large herbivore grazing, which prevented forest growth (Konvička et al. 2005; Pöyry et al. 2005; Krauss et al. 2005; Stefanescu et al. 2009). The co-existence of various herbivore species with varying feeding preferences and abundances led to strong spatial heterogeneity in herbal vegetation, while fluctuating grazer densities increased temporal dynamics of habitats (Morris 2000; Saarinen and Jantunen 2005; Öckinger et al. 2006; Rösch et al. 2013). Trampling providing continuous disturbance and the provision of dung which fertilised soils were additional positive impacts. All the aforementioned factors resulted in high plant species richness, which in turn benefited butterfly communities as well as various other insect taxa (Van Klink et al. 2015).

With increasing human population in Europe, wild grazers were decimated or even completely exterminated (e.g., aurochs), but since ancient times their role in maintaining butterfly habitats in favourable state was replaced by human activities (Bakker et al. 2004; Van Klink et al. 2015). Traditional agriculture supported the existence of a diverse mosaic of flower meadows mowed with variable intensity and timing, extensively grazed hillsides, and country roads (Balmer and Erhardt 2000; Morris 2000; Konvička et al. 2005). In turn, forest areas, comprising the second most important butterfly habitat (Warren and Bourn 2011), used to be cut frequently, which provided sufficient amount of sunny places (Kodandaramaiah et al. 2012; Fartmann et al. 2013; Slámová et al. 2013). During the twentieth century, mechanisation in both agriculture and forestry brought the era of intensive land use (Young et al. 2005; Wrbka et al. 2008; Korösi et al. 2014), and the traditional land use practices were no longer economically viable (Konvicka et al. 2005; Henle et al. 2008). Consequently, the land became either intensively used or abandoned, which led to population declines in numerous butterfly species (Dover et al. 2010; Horák et al. 2013; Loos et al. 2014).

In order to reverse the negative impacts of changes in agriculture on biodiversity the European Union has reformed its Common Agricultural Policy, focusing it on achieving an optimal balance between food production and sustaining biodiversity (Henle et al. 2008; Wrbka et al. 2008; EEA 2011). Currently, one of its most important instruments are agri-environmental schemes, which subsidise farmers for applying biodiversity-friendly agricultural practices, often resembling the traditional ones (Wätzold et al. 2008; Wrbka et al. 2008). Nevertheless, the pan-European mechanisms of Common Agricultural Policy have so far failed to improve the situation for butterflies, especially those of conservation concern (Henle et al. 2008; Warren and Bourn 2011).

If no further actions are taken, it is most likely that butterfly populations will keep declining and species extinctions will continue. Therefore, it seems necessary that butterfly persistence in semi-natural habitats of Europe is supported with appropriate conservation-oriented management of their sites, e.g., within nature reserves or Natura 2000 areas (van Swaay and Warren 2006; Pöyry 2007; van Swaay et al. 2012). Our review offers some rule-of-thumb recommendations in this respect.

The baseline should be stopping further destruction or devastation of butterfly habitats through ill-conceived management activities, such as afforestation of open lands or drainage works. However, the elimination of unsuitable management alone is not enough to improve the status of endangered butterfly species (van Swaay and Warren 2006; WallisDeVries and Ens 2010; van Swaay et al. 2012). If left abandoned, their habitats will gradually deteriorate in quality, and eventually they will turn into forest through vegetation succession (Bartel and Sexton 
2009). Consequently, it is necessary to implement practices aimed at preventing succession processes.

Extensive grazing and rotational mowing have been demonstrated to be the most suitable types of management in this respect, benefiting various groups of endangered butterflies (Dover et al. 2010). These types of management imitate the traditional way of meadow use (Saarinen and Jantunen 2005; Loos et al. 2014). D'Aniello et al. (2011), who compared the effects of grazing and mowing for meadow butterflies, found that grazing is generally more effective in maximising the number of butterfly species occurring in meadows; however, low intensity mosaic mowing provides almost equally positive results.

Trampling is an integral part of grazing, and it typically supports butterfly communities as well (Morris 2000). In areas lacking grazing, trampling can be achieved through various sport activities, e.g., hiking, biking, or horseback riding (Konvička et al. 2005). It has also been found that occasional small area burning is beneficial for a wide spectrum of butterfly species (Möllenbeck et al. 2009; McIver and Macke 2014). In addition, the active removal of shrubs and young trees may at times be necessary, especially because even their minor expansion threatens the populations of some butterfly species (Stefanescu et al. 2009). Conversely, certain species may actually profit from the presence of bushes within their habitats; therefore, the initial stages of succession should be allowed in such cases (Stuhldreher and Fartmann 2014). Other specific management types are suitable for butterflies associated with forests. For a relatively large group of endangered woodland species, maintaining (or, if necessary, establishing) forest glades and other sunny enclaves, as well as thinning forest stands, is recommended (Slámová et al. 2013; Maes et al. 2014).

It is also worth mentioning that apart from targeted management actions as described above butterflies can also benefit indirectly from various other human activities, specifically those suppressing natural succession. A classic example here are military training grounds, characterised by relatively frequent disturbances caused by blasts or heavy vehicles on one hand and the exclusion of intensive agriculture and forestry on the other (Ferster and Vulinec 2010; Rivers et al. 2010). Such conditions result in the formation of heterogeneous landscapes, which often support high diversity of butterflies with various habitat requirements (Warren et al. 2007; Čižek et al. 2013). Abandoned quarries are also known to provide a favourable, if atypical, environment for many animal and plant species (Tropek et al. 2010; Verovnik et al. 2013). Although quarry operations represent a dramatic land degradation; shortly after their abandonment spontaneous succession turns them into diverse habitat mosaics supporting a rich butterfly fauna (Novák and Konvička 2006;
Tropek et al. 2010, Čermáková et al. 2010). A similar situation can be observed in other artificial environments especially those created by infrastructure development, such as road margins, railway embankments, gravel pits, or ruderal habitats in suburbia (Van Geert et al. 2010; Lenda et al. 2012; Moron et al. 2014; Nowicki et al. 2013). Nevertheless, it must be underlined that such man-made environments offer favourable conditions only in their early successional stages, hence only in the short-term, and later on they require management just like natural habitats in order to prevent overgrowing.

In our paper, we primarily dealt with management types that should be promoted or prevented at the local scale of butterfly sites. Therefore, it is important to note that the actions favouring butterfly populations at the small-scale, will not necessarily be similarly favourable if applied at the large-scale. The most obvious example is the case of prescribed burning, but the same principle is true also for most other management types discussed. Besides, it should be kept in mind that many suitable management types are interconnected and that there can be no general recommendations on how to manage a particular habitat type. Finding a clear solution concerning the most appropriate management practice for any butterfly species depends on its species-specific habitat requirements, and for this reason it demands profound knowledge of the focal species ecology. Hence deciding an optimal management may be difficult, especially for species with highly specialised requirements (Schirmel and Fartmann 2014). Furthermore, the management of a locality must take into account the requirements of all of the species of conservation concern inhabiting it. These species may in fact have conflicting needs, and prioritising selected species would be essential in such cases (cf. Schmeller et al. 2008).

Acknowledgments This work was supported by the Internal Grant Agency of the Czech University of Life Sciences Prague (CIGA) through Project No. 20152004, and by the Polish National Science Centre through its Grant DEC-2013/11/B/NZ8/00912. We are grateful to Brian Kavalir for improving the English of the manuscript.

Open Access This article is distributed under the terms of the Creative Commons Attribution 4.0 International License (http://crea tivecommons.org/licenses/by/4.0/), which permits unrestricted use, distribution, and reproduction in any medium, provided you give appropriate credit to the original author(s) and the source, provide a link to the Creative Commons license, and indicate if changes were made.

\section{References}

AOPK (2011) Záchranný program hnědáska osikového (Euphydryas maturna) v České republice. MŽP ČR, Praha

Atay E (2012) The Genital Morphology and Major Taxonomic Characteristics of Zerynthia deyrollei (Oberthür, 1869) and 
Zerynthia cerisyi (Godart, 1822) (Lepidoptera: Papilionidae: Zerynthiinae). Pak J Zool 44:1343-1347

Augenstein B, Ulrich W, Habel JC (2012) Directional temporal shifts in community structure of butterflies and ground beetles in fragmented oligotrophic grasslands of Central Europe. Basic Appl Ecol 13:715-724

Bakker E, Olff H, Vandenberghe C, De Maeyer K, Smit R, Gleichman J, Vera F (2004) Ecological anachronisms in the recruitment of temperate light demanding tree species in wooded pastures. J Appl Ecol 41:571-582

Balmer O, Erhardt A (2000) Consequences of succession on extensively grazed grasslands for central European butterfly communities: rethinking conservation practices. Conserv Biol 14:746-757

Barea-Azcón JM, Benito BM, Olivares FJ, Ruiz H, Martín J, García AL, López R (2014) Distribution and conservation of the relict interaction between the butterfly Agriades zullichi and its larval foodplant (Androsace vitaliana nevadensis). Biodivers Conserv 23:927-944

Bartel RA, Sexton JO (2009) Monitoring habitat dynamics for rare and endangered species using satellite images and niche-based models. Ecography 32:888-896

Bauerfeind SS, Theisen A, Fischer K (2009) Patch occupancy in the endangered butterfly Lycaena helle in a fragmented landscape: effects of habitat quality, patch size and isolation. J Insect Conserv 13:271-277

Begon M, Townsend C, Harper J (2006) Ecology from individuals to ecosystems. Blackwell Publishing, Liverpool

Beneš J, Konvička M, Dvořák J, Fric Z, Havelda Z, Pavličko A, Vrabev V, Weidenhoffer Z (2002) Motýli České republiky: Rozšîrení a ochrana I, II. Společnost pro ochranu motýlů, Praha

Beneš J, Kepka P, Konvička M (2003) Limestone quarries as refuges for European xerophilous butterflies. Conserv Biol 17: $1058-1069$

Benton TG, Vickery JA, Wilson JD (2003) Farmland biodiversity: is habitat heterogeneity the key? Trends Ecol Evol 18:182-188

Bergman KO (1999) Habitat utilization by Lopinga achine (Nymphalidae: Satyrinae) larvae and ovipositing females: implications for conservation. Biol Conserv 88:69-74

Bergman KO (2001) Population dynamics and the importance of habitat management for conservation of the butterfly Lopinga achine. J Appl Ecol 38:1303-1313

Bohlin T, Tullberg BS, Merilaita S (2008) The effect of signal appearance and distance on detection risk in an aposematic butterfly larva (Parnassius apollo). Anim Behav 76:577-584

Bolotov I (2011) Fauna and ecology of butterflies (Lepidoptera, Rhopalocera) from Kanin Peninsula and Kolguev Island. Zool Zh 90:1365-1373

Britten HB, Brussard PF (1992) Genetic divergence and the Pleistocene history of the alpine butterflies Boloria improba (Nymphalidae) and the endangered Boloria acrocnema (Nymphalidae) in western North America. Can J Zool 70:539-548

Brommer J, Fred MS (1999) Movement of the Apollo butterfly Parnassius apollo related to host plant and nectar plant patches. Ecol Entomol 24:125-131

Buček A (2010) Význam starobylých výmladkových lesů v kulturní krajině České republiky. In: Mendelu Z (ed) Fórum o krajině a workshop management kulturní krajiny, Brno

Casacci LP, Witek M, Barbero F, Patricelli D, Solazzo G, Balletto E, Bonelli S (2011) Habitat preferences of Maculinea arion and its Myrmica host ants: implications for habitat management in Italian Alps. J Insect Conserv 15:103-110

Cassel A, Tammaru T (2003) Allozyme variability in central, peripheral and isolated populations of the scarce heath (Coenonympha hero: Lepidoptera, Nymphalidae); implications for conservation. Conserv Genet 4:83-93
Cassel A, Windig J, Nylin S, Wiklund C (2001) Effects of population size and food stress on fitness-related characters in the scarce heath, a rare butterfly in western Europe. Conserv Biol 15:1667-1673

Cassel A, Sjögren P, Berglind SA (2008) Effects of patch characteristics and isolation on relative abundance of the scarce heath butterfly Coenonympha hero (Nymphalidae). J Insect Conserv $12: 477-482$

Čelik T (2013) Oviposition preferences of a threatened butterfly Leptidea morsei (Lepidoptera: Pieridae) at the western border of its range. J Insect Conserv 17:865-876

Čelik T, Vreš B, Seliškar A (2009) Determinants of within-patch microdistribution and movements of endangered butterfly Coenonympha oedippus (Fabricius, 1787) (Nymphalidae: Satyrinae). Hacquetia 8:115-128

Čermáková Z, Fric Z, Martis M, Pecharová E (2010) Does landscape management influence butterfly diversity and abundance? J Landscape Stud 3:231-236

Cerrato C, Bonelli S, Loglisci N, Balletto E (2014) Can the extinction of Melitaea britomartis in NW Italy be explained by unfavourable weather? An analysis by optimal interpolation. J Insect Conserv 18:163-170

Čizek O, Konvička M (2005) What is a patch in a dynamic metapopulation? Mobility of an endangered woodland butterfly, Euphydryas maturna. Ecography 28:791-800

Čižek O, Vrba P, Beneš J, Hrazsky Z, Koptik J, Kučera T, Marhoul P, Zamečník J, Konvička M (2013) Conservation potential of abandoned military areas matches that of established reserves: plants and butterflies in the Czech Republic. PLoS ONE 8:e53124

Coutsis J, Ghavalás N (2001) The skippers and butterflies of the Greek part of the Rodópi massif (Lepidoptera: Hesperioidea \& Papilionoidea). Phegea 29:143-158

Cozzi G, Müller CB, Krauss J (2008) How do local habitat management and landscape structure at different spatial scales affect fritillary butterfly distribution on fragmented wetlands? Landscape Ecol 23:269-283

Cupedo F (2000) Die geographische Variabilitat von Erebia flavofasciata, nebst Beschreibung einer neuen Unterart (Nymphalidae: Satyrinae). Nota Lepid 23:173-184

Cuvelier S, Mølgaard M (2015) Pseudochazara amymone (Lepidoptera, Nymphalidae) in Albania: variability analysis, androconial scales and new distributional data. Nota Lepid 38:1-22

D'Aniello B, Stanislao I, Bonelli S, Balletto E (2011) Haying and grazing effects on the butterfly communities of two Mediterranean-area grasslands. Biodivers Conserv 20:1731-1744

de Arce-Crespo J, Jiménez-Mendoza S, Sánchez-Fernández P (2009) Information about the geographical and ecological distribution of the butterflies protected in the province of Cuenca, Spain (Insecta: Lepidoptera). SHILAP-Rev Lepidopt 37:209-227

Dennis RLH, Eales HT (1997) Patch occupancy in Coenonympha tullia (Muller, 1764) (Lepidoptera: Satyrinae): habitat quality matters as much as patch size and isolation. J Insect Conserv 1:167-176

Dincă V, Kolev Z, Verovnik R (2010) The distribution, ecology and conservation status of the Spinose Skipper Muschampia cribrellum (Eversmann, 1841) at the western limit of its range in Europe (Hesperiidae). Nota Lepid 33:39-57

Dincă V, Cuvelier S, Székely L, Vila R (2009) New data on the Rhopalocera (Lepidoptera) of Dobrogea (south-eastern Romania). Phegea 37:1-21

Dincă V, Runquist M, Nilsson M, Vila R (2013) Dispersal, fragmentation, and isolation shape the phylogeography of the European lineages of Polyommatus (Agrodiaetus) ripartii (Lepidoptera: Lycaenidae). Biol J Linn Soc 109:817-829

Dolek M, Geyer A (1997) Influence of management on butterflies of rare grassland ecosystems in Germany. $\mathrm{J}$ Insect Conserv $1: 125-130$ 
Dolek M, Geyer A (2002) Conserving biodiversity on calcareous grasslands in the Franconian Jura by grazing: a comprehensive approach. Biol Conserv 104:351-360

Dover J, Settele J (2009) The influences of landscape structure on butterfly distribution and movement: a review. J Insect Conserv 13:3-27

Dover JW, Rescia A, Fungarino S, Fairburn J, Carey P, Lunt P, Dennis RLH, Dover CJ (2010) Can hay harvesting detrimentally affect adult butterfly abundance? J Insect Conserv 14:413-418

Eichel S, Fartmann T (2008) Management of calcareous grasslands for Nickerl's fritillary (Melitaea aurelia) has to consider habitat requirements of the immature stages, isolation, and patch area. J Insect Conserv 12:677-688

Elmes GW, Thomas JA, Wardlaw JC, Hochberg ME, Clarke RT, Simcox DJ (1998) The ecology of Myrmica ants in relation to the conservation of Maculinea butterflies. J Insect Conserv 2:67-78

Farruggia A, Dumont B, Scohier A, Leroy T, Pradel P, Garel JP (2012) An alternative rotational stocking management designed to favour butterflies in permanent grasslands. Grass Forage Sci 67:136-149

Fartmann T, Müller C, Poniatowski D (2013) Effects of coppicing on butterfly communities of woodlands. Biol Conserv 159:396-404

Ferster B, Vulinec K (2010) Population size and conservation of the last eastern remnants of the regal fritillary, Speyeria idalia (Drury) [Lepidoptera, Nymphalidae]; implications for temperate grassland restoration. J Insect Conserv 14:31-42

Fischer K, Beinlich B, Plachter H (1999) Population structure, mobility and habitat preferences of the violet copper Lycaena helle (Lepidoptera: Lycaenidae) in Western Germany: implications for conservation. J Insect Conserv 3:43-52

Freese A, Dolek M, Geyer A, Stetter H (2005) Biology, distribution, and extinction of Colias myrmidone (Lepidoptera, Pieridae) in Bavaria and its situation in other European countries. J Res Lepidoptera 38:51-58

Freese A et al (2006) Habitat use of the endangered butterfly Euphydryas maturna and forestry in Central Europe. Anim Conserv 9:388-397

Fric Z, Hula V, Klimova M, Zimmermann K, Konvicka M (2010) Dispersal of four fritillary butterflies within identical landscape. Ecol Res 25:543-552

Gaisler J, Vilém P, Mládek J, Hejcman M, Pavlů L (2011) Obhospodařování travních porostů ve vztahu k agroenvironmentálním opatřením. VÚRV, Praha

Goffart P, Schtickzelle N, Turlure C (2010) Conservation and management of the habitats of two relict butterflies in the Belgian Ardenne: Proclossiana eunomia and Lycaena helle. Springer, Berlin, pp 357-370

Grill A, Cleary DFR (2003) Diversity patterns in butterfly communities of the Greek nature reserve Dadia. Biol Conserv 114:427-436

Grill A, Cleary DFR, Stettmer C, Bräu M, Settele J (2008) A mowing experiment to evaluate the influence of management on the activity of host ants of Maculinea butterflies. J Insect Conserv 12:617-627

Guillaumin M (1972) Analyse des differences de taille (T) et de forme (dh de Sneath). Comparaisons entre individus et entre caracteristiques moyennes de populations de Pyrgus carlinae et $P$. cirsii (Lep. hesperiidae). Arch Zool Exp Gen pp 465-488

Habel JC, Schmitt T, Meyer M, Finger A, RoeDder D, Assmann T, Zachos FE (2010) Biogeography meets conservation: the genetic structure of the endangered lycaenid butterfly Lycaena helle (Denis \& Schiffermüller, 1775). Biol J Linn Soc 101:155-168

Habel JC, Finger A, Schmitt T, Neve G (2011a) Survival of the endangered butterfly Lycaena helle in a fragmented environment: Genetic analyses over 15 years. J Zool Syst Evol Res 49:25-31
Habel JC, Roedder D, Schmitt T, Neve G (2011b) Global warming will affect the genetic diversity and uniqueness of Lycaena helle populations. Glob Change Biol 17:194-205

Haddad NM (1999) Corridor and distance effects on interpatch movements: a landscape experiment with butterflies. Ecol Appl 9:612-622

Háková A, Klaudisová A, Sádlo J (2005) Zásady péče o nelesní biotopy v rámci soustavy Natura 2000. MŽP, Praha

Hambäck PA, Bergman KO, Bommarco R, Krauss J, Kuussaari M, Pöyry J, Öckinger E (2010) Allometric density responses in butterflies: the response to small and large patches by small and large species. Ecography 33:1149-1156

Hanski I, Kuussaari M, Nieminen M (1994) Metapopulation structure and migration in the butterfly Melitaea cinxia. Ecology 75:747-762

Hanski I, Pakkala T, Kuussaari M, Lei G (1995) Metapopulation persistence of an endangered butterfly in a fragmented landscape. Oikos pp 21-28

Henle K, Alard D, Clitherow J, Cobb P, Firbank L, Kull T, McCracken D, Moritz RF, Niemelä J, Rebane M (2008) Identifying and managing the conflicts between agriculture and biodiversity conservation in Europe-a review. Agric Ecosyst Environ 124:60-71

Horák J, Peltanová A, Podavková A, Šafařová L, Bogusch P, Romportl D, Zasadil P (2013) Biodiversity responses to land use in traditional fruit orchards of a rural agricultural landscape. Agric Ecosyst Environ 178:71-77

Höttinger H (2004) Verbreitung, Ökologie, Gefährdung und Schutz des Senf-Weißlings Leptidea morsei (FENTON, 1881) in Österreich, insbesondere im Burgenland (Lepidoptera, Pieridae). Joannea Zool 6:187-206

Hula V, Konvicka M, Pavlicko A, Fric Z (2004) Marsh Fritillary (Euphydryas aurinia) in the Czech Republic: monitoring, metapopulation structure, and conservation of an endangered butterfly. Entomol Fennica 15:231-241

Humbert JY, Ghazoul J, Sauter GJ, Walter T (2010) Impact of different meadow mowing techniques on field invertebrates. J Appl Entomol 134:592-599

Hüseyinoğlu Y (2013) A faunistic study on Papilionoidea and Hesperioidea (Lepidoptera) of Murat mountain in Banaz, UŞAK province, Turkey. Pak J Zool 45:437-445

Johannesen J, Schwing U, Seufert W, Seitz A, Veith M (1997) Analysis of gene flow and habitat patch network for Chazara briseis (Lepidoptera: Satyridae) in an agricultural landscape. Biochem Syst Ecol 25:419-427

Johst K, Drechsler M, Thomas J, Settele J (2006) Influence of mowing on the persistence of two endangered large blue butterfly species. J Appl Ecol 43:333-342

Jones MJ, Lace LA (1992) The speckled wood butterflies Pararge xiphia and $P$. aegeria (Satyridae) on Madeira: distribution, territorial behaviour and possible competition. Biol J Linn Soc 46:77-89

Joy J, Pullin A (1997) The effects of flooding on the survival and behaviour of overwintering large heath butterfly Coenonympha tullia larvae. Biol Conserv 82:61-66

Joy J, Pullin A (1999) Field studies on flooding and survival of overwintering large heath butterfly Coenonympha tullia larvae on Fenn's and Whixall Mosses in Shropshire and Wrexham, UK. Ecol Entomol 24:426-431

Kadlec T, Vrba P, Konvička M (2009) Microhabitat requirements of caterpillars of the critically endangered butterfly Chazara briseis (Nymphalidae: Satyrinae) in the Czech Republic. Nota Lepid 32:39-46

Kadlec T, Vrba P, Kepka P, Schmitt T, Konvička M (2010) Tracking the decline of the once-common butterfly: delayed oviposition, 
demography and population genetics in the hermit Chazara briseis. Anim Conserv 13:172-183

Kajzer-Bonk J, Nowicki P, Bonk M, Skórka P, Witek M, Woyciechowski M (2013) Local populations of endangered Maculinea (Phengaris) butterflies are flood resistant. J Insect Conserv 17:1105-1112

Kati V, Zografou K, Tzirkalli E, Chitos T, Willemse L (2012) Butterfly and grasshopper diversity patterns in humid Mediterranean grasslands: the roles of disturbance and environmental factors. J Insect Conserv 16:807-818

Kleyer M et al (2007) Mosaic cycles in agricultural landscapes of Northwest Europe Basid. Appl Ecol 8:295-309

Kodandaramaiah U, Konvička M, Tammaru T, Wahlberg N, Gotthard K (2012) Phylogeography of the threatened butterfly, the woodland brown Lopinga achine (Nymphalidae: Satyrinae): implications for conservation. J Insect Conserv 16:305-313

Kolev Z (2003) First record of Muschampia cribrellum in Bulgaria, with a review of the recorded distribution of genus Muschampia in the country (Lepidoptera: Hesperiidae). Phegea 31:15-21

Kolev Z (2005) Polyommatus dantchenkoi (Lukhtanov \& Wiemers, 2003) tentatively identified as new to Europe, with a description of a new taxon from the Balkan Peninsula (Lycaenidae). Nota Lepid 28:25

Konvička M, Kuras T (1999) population structure, behaviour and selection of oviposition sites of an endangered butterfly, Parnassius Mnemosyne, in Litovelské Pomoravíl, Czech Republic. J Insect Conserv 3:211-223

Konvička M, Beneš J, Čížek L (2005) Ohrožený hmyz nelesních stanovišt': ochrana a management. Sagittaria, Olomouc

Konvička M, Beneš J, Čízek O, Kopeček F, Konvička O, Vitaz L (2008a) How too much care kills species: grassland reserves, agri-environmental schemes and extinction of Colias myrmidone (Lepidoptera: Pieridae) from its former stronghold. J Insect Conserv 12:519-525

Konvička M et al (2008b) The last population of the Woodland Brown butterfly (Lopinga achine) in the Czech Republic: habitat use, demography and site management. J Insect Conserv 12:549-560

Konvička M, Mihaly CV, Rákosy L, Beneš J, Schmitt T (2014) Survival of cold-adapted species in isolated mountains: the population genetics of the Sudeten ringlet, Erebia sudetica sudetica, in the Jeseník Mts, Czech Republic. J Insect Conserv 18:153-161

Korb S (1994) Vertical-distribution of Rhapalocera (Lepidoptera) within the Kirghiz mountain ridge. Zool Zh 73:123-129

Koren T, Jugovic J (2012) New data on the presence of three similar species of the genus Melitaea: M. athalia, M. aurelia and $M$. britomartis (Lepidoptera: Nymphalidae) in the north-western Balkans. Annales 22:25-34

Koren T, Bjelic M, Bozinovska E, Stih A, Buric I (2011) Contribution to the knowledge of butterfly fauna (Lepidoptera: Rhopalocera) of Zrmanja river region, Croatia. Acta Entomol Slov 19:155-168

Körösi Á, Oervoessy N, Batary P, Harnos A, Peregovits L (2012) Different habitat selection by two sympatric Maculinea butterflies at small spatial scale. Insect Conserv Diver 5:118-126

Kőrösi Á, Szentirmai I, Batáry P, Kövér S, Örvössy N, Peregovits L (2014) Effects of timing and frequency of mowing on the threatened scarce large blue butterfly-a fine-scale experiment. Agric Ecosyst Environ 196:24-33

Kozlov MV, Kullberg J (2008) Lepidoptera of tundra habitats of the northern Kola Peninsula, Northwestern Russia. Entomol Fenn 19:114

Krauss J, Steffan-Dewenter I, Müller CB, Tscharntke T (2005) Relative importance of resource quantity, isolation and habitat quality for landscape distribution of a monophagous butterfly. Ecography 28:465-474
Kruess A, Tscharntke T (2002) Grazing intensity and the diversity of grasshoppers, butterflies, and trap-nesting bees and wasps. Conserv Biol 16:1570-1580

Kudrna O, Pennerstorfer J, Lux K (2015) Distribution atlas of European butterflies and skippers. PEKS, Schwanfeld

Kuras T, Konvička M, Beneš J, Čižek O (2001) Erebia sudetica and Erebia epiphron (Lepidoptera: Nymphalidae, Satyrinae) in the Czech Republic: review of present and past distribution, conservation implications. Cas Slez Muz Opava 50:57-81

Kuras T, Beneš J, Fric Z, Konvička M (2003) Dispersal patterns of endemic alpine butterflies with contrasting population structures: Erebia epiphron and E. sudetica. Popul Ecol 45:115-123

Leigheb G, Cameron-Curry V, Riboni E, Cecchin S (1998) Present knowledge on the distribution of Erebia christi (Nymphalidae: Satyrinae) in the Italian Alps. Nota Lepid 21:290-295

Lelo S (2000) Revised inventory of the butterflies of Bosnia and Herzegovina (Insecta: Lepidoptera: Hesperioidea, Papilionoidea). Natura Croatica 9:139-156

Lelo S, Spasojević P (2012) A new find of eastern festoon, Zerynthia cerisyi (GODART, 1824) (Lepidoptera, Papilionidae), in Bosnia and Herzegovina. Uzizaž Biospeld 8:21-26

Lenda M, Skórka P, Moroń D, Rosin ZM, Tryjanowski P (2012) The importance of the gravel excavation industry for the conservation of grassland butterflies. Biol Conserv 148:180-190

Loos J, Dorresteijn I, Hanspach J, Fust P, Rakosy L, Fischer J (2014) Low-intensity agricultural landscapes in transylvania support high butterfly diversity: implications for conservation. PLoS ONE 9:e103256

Louy D, Habel JC, Schmitt T, Assmann T, Meyer M, Müller P (2007) Strongly diverging population genetic patterns of three skipper species: the role of habitat fragmentation and dispersal ability. Conserv Genet 8:671-681

Łozowski B, Kędziorski A, Nakonieczny M, Łaszczyca P (2014) Parnassius apollo last-instar larvae development prediction by analysis of weather condition as a tool in the species' conservation. CR Biol 337:325-331

Luoto M, Kuussaari M, Rita H, Salminen J, Bonsdorff TV (2001) Determinants of distribution and abundance in the clouded apollo butterfly: a landscape ecological approach. Ecography 24:601-617

Maes D, Jacobs I, Segers N, Vanreusel W, Van Daele T, Laurijssens G, Van Dyck H (2014) A resource-based conservation approach for an endangered ecotone species: the Ilex Hairstreak (Satyrium ilicis) in Flanders (north Belgium). J Insect Conserv 18:939-950

Marhoul P, Turoňová D (2007) Zásady managementu stanovišt' druhů v evropsky významných lokalitách soustavy Natura 2000. AOPK, Praha

Marttila O, Saarinen K, Jantunen J (1997) Habitat restoration and a successful reintroduction of the endangered Baton Blue butterfly (Pseudophilotes baton schiffermuelleri) in SE Finland. In: Annales Zoologici Fennici. JSTOR, pp 177-185

McIver J, Macke E (2014) Short-term butterfly response to sagebrush steppe restoration treatments. Rangeland Ecol Manag 67:539-552

Meier K, Kuusemets V, Luig J, Mander Ü (2005) Riparian buffer zones as elements of ecological networks: case study on Parnassius mnemosyne distribution in Estonia. Ecol Eng 24:531-537

Mládek J, Pavlů V, Hejcman M, Gaisler J (2006) Pastva jako prostředek údržby trvalých travních porostů $\mathrm{v}$ chráněných územích. VÚRV, Praha

Möllenbeck V, Hermann G, Fartmann T (2009) Does prescribed burning mean a threat to the rare satyrine butterfly Hipparchia fagi? Larval-habitat preferences give the answer. J Insect Conserv 13:77-87

Moroń D, Skórka P, Lenda M, Rożej-Pabijan E, Wantuch M, KajzerBonk J, Celary W, Mielczarek ŁE, Tryjanowski P (2014) 
Railway embankments as new habitat for pollinators in an agricultural landscape. PLoS ONE 9:e101297

Morris MG (2000) The effects of structure and its dynamics on the ecology and conservation of arthropods in British grasslands. Biol Conserv 95:129-142

Morris MG, Rispin WE (1987) Abundance and diversity of the coleopterous fauna of a calcareous grassland under different cutting regimes. J Appl Ecol 24:451-465

Munguira ML, Martín J (1993) The conservation of endangered lycaenid butterflies in Spain. Biol Conserv 66:17-22

MZE (2001) Zpráva o stavu lesa a lesního hospodaření v lesích České republiky k 31. 12. 2000. MZE ČR, Praha

Novák J, Konvička M (2006) Proximity of valuable habitats affects succession patterns in abandoned quarries. Ecol Eng 26:113-122

Novák J, Skalický M, Hakl J, Dvořáková E (2007) Habitat management for the protected Maculinea butterflies: the effect of mowing. Cereal Res Commun 35:857-860

Nowicki P, Halecki W, Kalarus K (2013) All natural habitat edges matter equally for endangered Maculinea butterflies. J Insect Conserv 17:139-146

Nowicki P, Vrabec V, Binzenhöfer B, Feil J, Zakšek B, Hovestadt T, Settele J (2014) Butterfly dispersal in inhospitable matrix: rare, risky, but long-distance. Landscape Ecol 29:401-412

Nowicki P, Marczyk J, Kajzer-Bonk J (2015) Metapopulations of endangered Maculinea butterflies are resilient to large-scale fire. Ecohydrology 8:398-405

Obregón R, Arenas-Castro S, Gil F, Jordano D, Fernández-Haeger J (2014) Biología, ecología y modelo de distribución de las especies del género Pseudophilotes Beuret, 1958 en Andalucía (Sur de España) (Lepidoptera: Lycaenidae). Shilap-Rev Lepidopt 42:501-515

Öckinger E, Smith HG (2006) Landscape composition and habitat area affects butterfly species richness in semi-natural grasslands. Oecologia 149:526-534

Öckinger E, Smith HG (2007) Semi-natural grasslands as population sources for pollinating insects in agricultural landscapes. J Appl Ecol 44:50-59

Öckinger E, Eriksson AK, Smith HG (2006) Effects of grassland abandonment, restoration and management on butterflies and vascular plants. Biol Conserv 133:291-300

Örvössy N, Kőrösi Á, Batáry P, Vozár A, Peregovits L (2013) Potential metapopulation structure and the effects of habitat quality on population size of the endangered False Ringlet butterfly. J Insect Conserv 17:537-547

Pennekamp F, Monteiro E, Schmitt T (2013) The larval ecology of the butterfly Euphydryas desfontainii (Lepidoptera: Nymphalidae) in SW-Portugal: food plant quantity and quality as main predictors of habitat quality. J Insect Conserv 17:195-206

Pennekamp F, Garcia-Pereira P, Schmitt T (2014) Habitat requirements and dispersal ability of the Spanish Fritillary (Euphydryas desfontainii) in southern Portugal: evidence-based conservation suggestions for an endangered taxon. J Insect Conserv 18:497-508

Pinzari M (2009) A comparative analysis of mating recognition signals in graylings: Hipparchia statilinus vs. H. semele (Lepidoptera: Nymphalidae, Satyrinae). J Insect Behav 22:227-244

Pinzari M, Sbordoni V (2013) Species and mate recognition in two sympatric Grayling butterflies: Hipparchia fagi and $H$. hermione genava (Lepidoptera). Ethol Ecol Evol 25:28-51

Pocewicz A, Morgan P, Eigenbrode SD (2009) Local and landscape effects on butterfly density in northern Idaho grasslands and forests. J Insect Conserv 13:593-601

Pöyry J (2007) Management of semi-natural grasslands for butterfly and moth communities. Environmental Institute, Helsinki

Pöyry J, Lindgren S, Salminen J, Kuussaari M (2005) Responses of butterfly and moth species to restored cattle grazing in seminatural grasslands. Biol Conserv 122:465-478
Pöyry J, Luoto M, Paukkunen J, Pykälä J, Raatikainen K, Kuussaari M (2006) Different responses of plants and herbivore insects to a gradient of vegetation height: an indicator of the vertebrate grazing intensity and successional age. Oikos 115:401-412

Rabasa SG, Gutiérrez D, Escudero A (2007) Metapopulation structure and habitat quality in modelling dispersal in the butterfly Iolana iolas. Oikos 116:793-806

Rabasa SG, Gutiérrez D, Escudero A (2008) Relative importance of host plant patch geometry and habitat quality on the patterns of occupancy, extinction and density of the monophagous butterfly Iolana iolas. Oecologia 156:491-503

Reidsma P, Tekelenburg T, Van den Berg M, Alkemade R (2006) Impacts of land-use change on biodiversity: an assessment of agricultural biodiversity in the European Union. Agric Ecosyst Environ 114:86-102

Rivers JW, Gipson PS, Althoff DP, Pontius JS (2010) Long-term community dynamics of small landbirds with and without exposure to extensive disturbance from military training activities. Environ Manage 45:203-216

Rösch V, Tscharntke T, Scherber C, Batary P (2013) Landscape composition, connectivity and fragment size drive effects of grassland fragmentation on insect communities. J Appl Ecol 50:387-394

Saarinen K, Jantunen J (2005) Grassland butterfly fauna under traditional animal husbandry: contrasts in diversity in mown meadows and grazed pastures. Biodivers Conserv 14:3201-3213

Sang A, Teder T, Helm A, Pärtel M (2010) Indirect evidence for an extinction debt of grassland butterflies half century after habitat loss. Biol Conserv 143:1405-1413

Sawchik J, Dufrêne M, Lebrun P (2003) Estimation of habitat quality based on plant community, and effects of isolation in a network of butterfly habitat patches. Acta Oecol 24:25-33

Schirmel J, Fartmann T (2014) Coastal heathland succession influences butterfly community composition and threatens endangered butterfly species. J Insect Conserv 18:111-120

Schmeller DS et al (2008) Determination of conservation priorities in regions with multiple political jurisdictions. Biodivers Conserv 17:3623-3630

Schmeller DS, Dolek M, Geyer A, Settele J, Brandl R (2011) The effect of conservation efforts on morphological asymmetry in a butterfly population. J Nat Conserv 19:161-165

Schmitt T, Rákosy L (2007) Changes of traditional agrarian landscapes and their conservation implications: a case study of butterflies in Romania. Divers Distrib 13:855-862

Schtickzelle N, Baguette M (2003) Behavioural responses to habitat patch boundaries restrict dispersal and generate emigrationpatch area relationships in fragmented landscapes. J Anim Ecol 72:533-545

Schtickzelle N, Choutt J, Goffart P, Fichefet V, Baguette M (2005) Metapopulation dynamics and conservation of the marsh fritillary butterfly: population viability analysis and management options for a critically endangered species in Western Europe. Biol Conserv 126:569-581

Schtickzelle N, Mennechez G, Baguette M (2006) Dispersal depression with habitat fragmentation in the bog fritillary butterfly. Ecology 87:1057-1065

Schurian K (1995) Biologie et ecologie de Polyommatus (Aricia) anteros. Linneana Belgica 1:27-32

Schweiger O, Settele J, Kudrna O, Klotz S, Kühn I (2008) Climate change can cause spatial mismatch of trophically interacting species. Ecology 89:3472-3479

Settele J (2010) Oedippus 26. Sofia, Moscow

Settele J et al (2008) Climatic risk atlas of European butterflies. Pensoft Sofia, Bulgaria

Seufert W, Grosser N (1996) A population ecological study of Chazara briseis (Lepidoptera, Satyrinae): Species survival in fragmented lands. Springer, Netherlands, pp 268-274 
Shreeve T, Smith A (1992) The role of weather-related habitat use on the impact of the European speckled wood Pararge aegeria on the endemic Pararge xiphia on the island of Madeira Biological. Biol J Linn Soc 46:59-75

Sielezniew M, Rutkowski R (2012) Population isolation rather than ecological variation explains the genetic structure of endangered myrmecophilous butterfly Phengaris (=Maculinea) arion. J Insect Conserv 16:39-50

Simonsen TJ (2005) Boloria phylogeny (Lepidoptera: Nymphalidae): tentatively reconstructed on the basis of male and female genitalic morphology. Syst Entomol 30:653-665

Skórka P, Settele J, Woyciechowski M (2007) Effects of management cessation on grassland butterflies in southern Poland. Agric Ecosyst Environ 121:319-324

Skórka P, Nowicki P, Lenda M, Witek M, Sliwińska EB, Settele J, Woyciechowski M (2013) Different flight behaviour of the endangered scarce large blue butterfly Phengaris teleius (Lepidoptera: Lycaenidae) within and outside its habitat patches. Landscape Ecol 28:533-546

Slámová I, Klecka J, Konvicka M (2013) Woodland and grassland mosaic from a butterfly perspective: habitat use by Erebia aethiops (Lepidoptera: Satyridae). Insect Conserv Diver 6:243-254

Šlancarová J, Bednářová B, Beneš J, Konvička M (2012) How life history affects threat status: requirements of two Onobrychisfeeding lycaenid butterflies, Polyommatus damon and Polyommatus thersites, in the Czech Republic. Biologia 67:1175-1185

Šlancarová J, Vrba P, Platek M, Zapletal M, Spitzer L, Konvička M (2015) Co-occurrence of three Aristolochia-feeding Papilionids (Archon apollinus, Zerynthia polyxena and Zerynthia cerisy) in Greek Thrace. J Nat Hist 49:29-30

Sliwinska EB, Nowicki P, Nash DR, Witek M, Settele J, Woychiechowski M (2006) Morphology of caterpillars and pupae of European Maculinea species (Lepidoptera: Lycaenidae) with an identification table. Entomol Fennica 17:351-358

Spitzer L, Beneš J, Dandová J, Jasková V, Konvička M (2009) The Large Blue butterfly, Phengaris (Maculinea) arion, as a conservation umbrella on a landscape scale: the case of the Czech Carpathians. Ecol Indic 9:1056-1063

Stefanescu C, PeNuelas J, Filella I (2009) Rapid changes in butterfly communities following the abandonment of grasslands: a case study. Insect Conserv Diver 2:261-269

Streitberger M, Hermann G, Kraus W, Fartmann T (2012) Modern forest management and the decline of the Woodland Brown (Lopinga achine) in Central Europe. Forest Ecol Manag 269:239-248

Stuhldreher G, Fartmann T (2014) When habitat management can be a bad thing: effects of habitat quality, isolation and climate on a declining grassland butterfly. J Insect Conserv 18:965-979

Szentirmai I, Mesterházy A, Varga I, Schubert Z, Sándor LC, Ábrahám L, Körösi Á (2014) Habitat use and population biology of the Danube Clouded Yellow butterfly Colias myrmidone (Lepidoptera: Pieridae) in Romania. J Insect Conserv $18: 417-425$

Thomas JA (1995) The ecology and conservation of Maculinea arion and other European species of large blue butterfly. Springer, Netherlands, pp 180-197

Thomas C, Thomas J, Warren M (1992) Distributions of occupied and vacant butterfly habitats in fragmented landscapes. Oecologia 92:563-567

Thomas JA et al (2001) The quality and isolation of habitat patches both determine where butterflies persist in fragmented landscapes. Proc R Soc Lond B Biol Sci 268:1791-1796

Thomas JA, Simcox DJ, Clarke RT (2009) Successful conservation of a threatened Maculinea butterfly. Science 325:80-83
Thomas JA, Simcox DJ, Hovestadt T (2011) Evidence based conservation of butterflies. J Inscect Conserv 15:241-258

Tropek R, Kadlec T, Karesová P, Spitzer L, Kočárek P, Malenovský I, Banar P, Tuf IH, Hejda M, Konvička M (2010) Spontaneous succession in limestone quarries as an effective restoration tool for endangered arthropods and plants. J Appl Ecol 47:139-147

Välimäki P, Itämies J (2003) Migration of the clouded Apollo butterfly Parnassius mnemosyne in a network of suitable habitats-effects of patch characteristics. Ecography 26:679-691

Van Geert A, Van Rossum F, Triest L (2010) Do linear landscape elements in farmland act as biological corridors for pollen dispersal? J Ecol 98:178-187

van Halder I, Barbaro L, Corcket E, Jactel H (2008) Importance of semi-natural habitats for the conservation of butterfly communities in landscapes dominated by pine plantations. Biodivers Conserv 17:1149-1169

Van Klink R, van der Plas F, van Noordwijk C, WallisDeVries MF, Olff $\mathrm{H}$ (2015) Effects of large herbivores on grassland arthropod diversity. Biol Rev 90:347-366

van Swaay C (2002) The importance of calcareous grasslands for butterflies in Europe. Biol Conserv 104:315-318

van Swaay C, Warren M (1999) Red data book of European butterflies (Rhopalocera) vol 99, Council of Europe

van Swaay C, Warren MS (2006) Prime butterfly areas of Europe: an initial selection of priority sitesfor conservation. J Insect Conserv 10:5-11

van Swaay C et al (2010) European red list of butterflies. Publications Office of the European Union, Luxembourg

van Swaay C et al (2011) Applying IUCN criteria to invertebrates: How red is the Red List of European butterflies? Biol Conserv 144:470-478

van Swaay C et al (2012) Dos and don'ts for butterflies of the habitats directive of the European Union. Nat Conserv 1:73-153

Verovnik R, Govedič M, Šalamun A (2011) Is the Natura 2000 network sufficient for conservation of butterfly diversity? A case study in Slovenia. J Insect Conserv 15:345-350

Verovnik R, Micevski B, Maes D, Wynhoff I, van Swaay C, Warren M (2013) Conserving Europe's most endangered butterfly: the Macedonian Grayling (Pseudochazara cingovskii). J Insect Conserv 17:941-947

Verovnik R, Popović M, Šašić M, Cuvelier S, Maes D (2014) Wanted! Dead or alive: the tale of the Brown's Grayling (Pseudochazara amymone). J Insect Conserv 18:675-682

Vrabec V (2001) Vzácný motýl České a Slovenské republikyhnědásek (hnědáčik): osikový (Euphydryas Maturna L.). Hmyz 2:4-9

WallisDeVries MF, Ens SH (2010) Effects of habitat quality and isolation on the colonization of restored heathlands by butterflies. Restor Ecol 18:390-398

WallisDeVries MF, Reemakers I (2001) Does extensive grazing benefit butterflies in coastal dunes. Restor Ecol 9:179-188

Warren MS (1992) Butterfly populations. In: Dennis RLH (ed) The ecology of butterflies in Britain. Oxford University Press, Oxford, pp 73-92

Warren MS, Bourn NA (2011) Ten challenges for 2010 and beyond to conserve Lepidoptera in Europe. J Insect Conserv 15:321-326

Warren SD, Holbrook SW, Dale DA, Whelan NL, Elyn M, Grimm W, Jentsch A (2007) Biodiversity and the heterogeneous disturbance regime on military training lands. Restor Ecol 15:606-612

Wätzold F, Lienhoop N, Drechsler M, Settele J (2008) Estimating optimal conservation in the context of agri-environmental schemes. Ecol Econ 68:295-305

Weking S, Hermann G, Fartmann T (2013) Effects of mire type, land use and climate on a strongly declining wetland butterfly. J Insect Conserv 17:1081-1091 
Wenzel M, Schmitt T, Weitzel M, Seitz A (2006) The severe decline of butterflies on western German calcareous grasslands during the last 30 years: a conservation problem. Biol Conserv 128:542-552

Wiemers M, Stradomsky BV, Vodolazhsky DI (2010) A molecular phylogeny of Polyommatus s. str. and Plebicula based on mitochondrial COI and nuclear ITS2 sequences (Lepidoptera: Lycaenidae). Eur J Entomol 107:325-336

Witek M, Nowicki P, ŚLiwińska EB, Skórka P, Settele J, Schoenrogge K, Woyciechowski M (2010) Local host ant specificity of Phengaris (Maculinea) teleius butterfly, an obligatory social parasite of Myrmica ants. Ecol Entomol 35:557-564

Witek M, Skórka P, Śliwińska EB, Nowicki P, Moroń D, Settele J, Woyciechowski M (2011) Development of parasitic Maculinea teleius (Lepidoptera, Lycaenidae) larvae in laboratory nests of four Myrmica ant host species. Insect Soc 58:403-411

Wolf A (2002) Conservation Assessment for Northern Blue Butterfly_Plebejus (Lycaeides): Idas Nabokovi, Masters and Drawf
Bilberry-Vaccinium caespitosum (Michx). vol Ph. D. University of Wisconsin-Green Bay, Wisconsin, Green Bay

Wrbka T, Schindler S, Pollheimer M, Schmitzberger I, Peterseil J (2008) Impact of the Austrian Agri-Environmental Scheme on diversity of landscapes, plants and birds. Community Ecol 9:217-227

Wynhoff I, Van Gestel R, Van Swaay C, Van Langevelde F (2011) Not only the butterflies: managing ants on road verges to benefit Phengaris (Maculinea) butterflies. J Insect Conserv 15:189-206

Young $\mathbf{J}$ et al (2005) Towards sustainable land use: identifying and managing the conflicts between human activities and biodiversity conservation in Europe. Biodivers Conserv 14:1641-1661

Zimmermann K et al (2011) Demography of adults of the Marsh fritillary butterfly, Euphydryas aurinia (Lepidoptera: Nymphalidae) in the Czech Republic: Patterns across sites and seasons. Eur J Entomol 108:243-254 